\title{
Bioremediation of Total Petroleum Hydrocarbon Polluted Soil From an Abadoned Illegal Crude Oil Refining Site Using Organic Amendments
}

\section{Douglas Salome Ibietela*, Ugboma CJ and Onwukwe J0}

Department of Microbiology, Faculty of Science, Rivers State University, Rivers

State, Nigeria

*Corresponding Author: Douglas Salome Ibietela, Department of Microbiology, Faculty of Science, Rivers State University, Rivers State, Nigeria.
Received: November 29, 2021

Published: December 27, 2021

(C) All rights are reserved by Douglas Salome

Ibietela., et al.

\section{Abstract}

This study was carried out to evaluate the bioremediation of total petroleum hydrocarbon (TPH) polluted soil from an abandoned illegal crude oil refining site using organic amendments: fish pond effluent (FPE), spent mushroom substrate (SMS) and compost soil (CS) from an old waste dump site. Baseline studies on the polluted soil samples were carried out. The treatment options were four experimental setups including control in clay pots. The setups were left to stand for 28days and monitored every 7 days using standard microbiological techniques and gas chromatography. The baseline TPH result was $25,350.2 \pm 0.21 \mathrm{mg} / \mathrm{kg}$. This was above the DPR intervention limit, which means remedial action is required. Total heterotrophic bacterial (THB) counts ranged from: $1.3 \pm 0.05$ x $10^{5}$ to $2.3 \pm 0.04 \times 10^{6} \mathrm{Cfu} / \mathrm{g}$, Total fungal counts ranged from $9.0 \pm 0.01 \times 10^{4}$ to $7.0 \pm 0.01 \times 10^{5} \mathrm{Cfu} / \mathrm{g}$, Hydrocarbon utilizing bacterial (HUB) counts ranged from $1.0 \pm 0.04 \times 10^{5}$ to $1.32 \pm 0.04 \times 10^{6} \mathrm{Cfu} / \mathrm{g}$, Hydrocarbon utilizing fungal (HUF) counts ranged from: $7.0 \pm 0.02 \times 10^{4}$ to $5.1 \pm 0.18 \times 10^{5} \mathrm{Cfu} / \mathrm{g}$ all across the setups. FPE gave a half-life of 9.6 days with TPH degradation of $88.27 \%$, SMS had TPH degradation of $82.12 \%$ with a half-life of 12.2 days, CS gave TPH degradation of $75.53 \%$ and a half-life of 14.81 days and the control had the least TPH degradation of 6.0\% and a longer half-life of 315.1 days. The following bacteria and fungi were isolated and identified: Psuedomonas sp, Bacillus sp, Micrococcus sp, Chromobacterium sp, Alcaligenes sp, Arthrobacter sp, Fusarium sp, Rhizopus sp, Mucor sp, Aspergillus fumigates, Penicillium sp, Cryptococcus sp, Aspergillus lentulus, Rhodotolola sp. These results show that, the addition of these amendments and the natural resident flora enhanced the TPH degradation, with FPE giving the highest bioremediation percent. Hence, FPE may be recommended to be applied in the bioremediation of petroleum polluted soil.

Keywords: Organic Amendments; Bioremediation; Total Petroleum Hydrocarbon; Biodegradation; Illegal Refinery

\section{Introduction}

Crude oil is a very essential source of energy in the world nonetheless, standard operations for extracting and drilling of this fossil energy resources has caused detrimental effects in our environment [1]. In the world today, soil is being destroyed due to the increasing industrial, civil and agricultural activities; contamination of soil both diffused and localized may lead to damage of many soil functions, surface water and groundwater contamination [1]. Many reclamation methods have been undertaken to clean up polluted soils. Physical, chemical and biological approaches are being followed in the remediation of polluted soils [2]. The physical and chemical methods are very cost intensive, laborious and sometimes, pollutants are not eliminated completely from the polluted site [3], leading to unwanted ecological consequences [4]. Hence, 
biological method is preferred which depends on microbial enzymatic processes to help remove the pollutant from the site of pollution [5].

Bioremediation is the application of biological treatment to clean up hazardous chemical. This process involves detoxification of the pollutant whereby; it is converted into less toxic substances and mineralized completely as the waste material can be converted into inorganic compounds like carbon dioxide, water, methane and sometimes fatty acids [6]. Bioremediation is not new to humans but new methods that originate from advances in molecular biology and process engineering are emerging. Bioremediation of hydrocarbon-contaminated soils, which uses the ability of microorganisms to degrade and detoxify organic contamination, has been proven as an efficient, economic, versatile, and environmentally sound treatment [7].

It has been proved that instead of bringing foreign microorganisms, the use of resident microbes is more advantageous [8]. This is because these resident microbes are already adapted to the environment over time, which makes their survival and growth easy. Also, they stated that the capacity to use hydrocarbon is distributed within different microbial populations. Wang., et al. [9] stated that, since microorganisms are found everywhere, pollutant degraders are also present in a polluted environment. Their population, diversity and metabolic activities in that environment may be more or less as a result of the pollutant concentration. Therefore, the introduction of agricultural waste that contains such essential nutrients (especially nitrogen, potassium and phosphorus) will be useful in taking care of the nutrient limitations in such polluted environments. Introduction of such waste as amendments to soil can lead to dilution effect and change the chemical components, thereby reducing the toxicity [10].

It is well known that a lot of soil bacteria and fungi can utilize petroleum hydrocarbons as a carbon source. At the same time, some indigenous microbes have gradually adapted to the long-term oil contaminated soil and developed a superior community which can make use of oil contaminants through special substrate enrichment [11]. Therefore, bioremediation of oil contaminated soil has broad prospects because of its low cost, no secondary pollution and processing in-situ [12]. The biodegradation of hydrocarbons especially total petroleum hydrocarbons takes place both in aerobic and anaerobic environments through metabolic and co-metabolic path- ways [13]. Aerobic biodegradation of these hydrocarbons is well known with proven pathways and specific metabolites for each aromatic hydrocarbon molecule [14]. Anaerobic biodegradation of these hydrocarbons is still very new and their metabolic pathways are still at the budding stage [13].

The pollution of soil with different types and classes of hydrocarbons resulting from the illegal refining of crude oil has been one of the greatest causes of environmental challenges in the Niger Delta [15]. Application of agricultural waste materials as a way of bio-stimulating the indigenous microbiota for the development of sustainable bioremediation process is important and timely.The aim of this study is to evaluate the effectiveness of fishpond effluent (FPE), spent mushroom substrate (SMS) and compost soil (CS) from an old dump site on the remediation of crude oil polluted soil from an abandoned illegal crude oil refining site.

\section{Materials and Methods}

\section{Sample collection}

Soil polluted with crude oil and petroleum products were collected from an abandoned illegal crude oil refining site location at Ngia Kiri in Degema Local Government Area of Rivers State, Nigeria, with the aid of soil auger, taken at $0-30 \mathrm{~cm}$ depth from different points, mixed together to form a composite sample and transported to the laboratory for analyses. The coordinate of the location is $4^{0} 78^{\prime} 60^{\prime \prime} \mathrm{N}, 6^{0} 89^{\prime} 24^{\prime \prime}$ E.

Spent mushroom substrate was taken from Rivers State University Agricultural farm, fish pond effluent was taken from a private fish pond farm in Woji Port Harcourt, Rivers State and the compost soil was taken from an old dumpsite in Eleme, all in Rivers State, Nigeria.

\section{Bioremediation experimental setup}

Baseline microbiology and TPH (gas chromatography) analysis of the soil sample were carried out. To evaluate the biodegradation of total petroleum hydrocarbon content, the polluted soil sample was weighed and set up in duplicates in clay pots. One thousand grams (1000 g) each of the soil was placed into 2 sterile pots, this was labeled as the control. Then into each of the other pots marked for the 3 amendments (FPE, SMS and CS), 900g of polluted soil was put in all the pots separately. Thereafter, $100 \mathrm{~g}$ of each amendment was added into the appropriate pot and mixed thoroughly, using 
ethanol-sterilized hand trowel. Sterile distilled water was added into each of the experimental setups, to maintain about $30 \%$ moisture content and mixed properly to increase aeration. This was done at 3 days interval; during the 28 days experimental period. Soil samples were taken out every 7 days for both microbial and residual petroleum hydrocarbon content. The setups were kept in green house throughout the duration of the work [15].

\begin{tabular}{|c|c|}
\hline Code & Description \\
\hline 1 (control) & $1000 \mathrm{~g}$ of polluted soil (PS) \\
\hline 2 (FPE) & $\begin{array}{c}\text { 900g of PS }+100 \mathrm{~g} \text { of dried fish pond effluent } \\
\text { substrate }\end{array}$ \\
\hline 3 (SMS) & $\begin{array}{c}900 \mathrm{~g} \text { of PS }+100 \mathrm{~g} \text { of dried spent mushroom } \\
4(\mathrm{CS})\end{array}$ \\
\hline
\end{tabular}

Table 1: Experimental set- up for the Bioremediation.

Key: FPE: Fishpond Effluent, SMS: Spent Mushroom Substrate, CS: Compost Soil, PS: Polluted Soil, with monitoring on days 0, 14 and 28.

Enumeration and isolation of total heterotrophic and hydrocarbon utilizing bacteria

One gram (1g) of soil sample from each treatment setup was suspended into $9.0 \mathrm{ml}$ of sterile normal saline which was serially diluted to $10^{-4}$. Then $0.1 \mathrm{ml}$ of $10^{-3}$ and $10^{-4}$ dilutions were spread on Nutrient agar plate in triplicates. The plates were incubated at $37^{\circ} \mathrm{C}$ for 24 hours and counts were taken after 24 hours. Hydrocarbon utilizing bacteria (HUB) were isolated and quantified using mineral salt medium composition of Mills., et al. [16] as modified by Okpokwasili and Okorie [17] supplemented with 1\% Bonny light crude oil. Approximately $0.1 \mathrm{ml}$ of $10^{-3}$ and $10^{-4}$ dilutions were plated out in triplicates too. The plates were incubated at $25^{\circ} \mathrm{C}$ for 5 to 7 days and colonies counted [15].

\section{Biochemical characterization of isolates}

The colonies that grew on Nutrient agar and Mineral salt agar plates were counted and distinct colonies sub-cultured on fresh sterile nutrient agar at $37^{\circ} \mathrm{C}$ for 24 hours so as to obtain pure isolates. The morphological characteristics of the pure colonies were observed which includes: the colony colour, shape, size, elevation, viscosity and form. Gram staining was also done for each of the pure isolates. The following biochemical tests: catalase, oxidase, ci- trate, indole, motility, Methyl red, Voges-Proskauer, sugar fermentation and starch hydrolysis were carried out for each isolate [18].

Total petroleum hydrocarbon (TPH) by G.C (FID)

\section{Soil sample extraction}

Ten gram $(10 \mathrm{~g})$ of soil samples were taken from each treatment setups and put into amber glass bottles respectively. Anhydrous sodium sulphate $\left(\mathrm{Na}_{2} \mathrm{SO}_{4}\right)$ was added into the amber glass bottles containing the soil samples and mixed evenly. About $300 \mu \mathrm{g} / \mathrm{ml}$ of surrogate (1-chlorooctadecane) standard was added to each soil sample and $30 \mathrm{ml}$ of dichloromethane (DCM) was put into each sample as extracting solvent then continuous mixing using a mechanical shaker for 5 to 6 hours. After agitation, the soil samples were allowed to settle for 1 hour then filtered using $110 \mathrm{~mm}$ filter paper into clean beakers appropriately. The filtrates were allowed to concentrate to $1 \mathrm{ml}$ by evaporation overnight in a fume cupboard [19].

\section{Sample separation and detection}

The separation and detection of compounds in soil samples were carried out using Agilent 6890N Gas Chromatograph - Flame Ionization Detector (GC-FID) instrument. About $3 \mu \mathrm{l}$ each of concentrated samples eluted from column were injected into GC vials separately. The blank DCM was injected into micro-syringe of GC to clean the syringe ( 3 times) before taking the samples for analysis. The micro-syringe was further rinsed with the extracted soil sample individually; the samples were injected into the column for separation of compounds in each sample. After separation the compounds were passed through a flame ionization detector which detects the compounds in the sample. The amount of TPH was resolved at a particular chromatogram in $\mathrm{mg} / \mathrm{kg}$ for the soil samples [19].

\section{Statistical Analyses}

One-way analysis of variance (ANOVA) was used to analyse data from the results of total heterotrophic bacterial and TPH degradation efficiency was gotten using IBM SPSS Version 21 to determine the level of significance at $\mathrm{p}<0.05$ and half-life to determine time it took to degrade half the quantity of pollutant present in the soil sample. Excel inbuilt statistical package was used for graphical illustration of data. 
Degradation efficiency or percentage reduction $=\mathrm{TPH}$ initial concentration - TPH final concentration/ TPH initial concentration X 100--------Eq. 1

Half-life $=\operatorname{In} 2 / \mathrm{K}=0.6932 / \mathrm{k}----\cdot----E q \ldots \ldots \ldots \ldots \ldots \ldots . . .2$

Where $\mathrm{K}$ is the biodegradation rate constant [20].

\section{Results}

The baseline study of the polluted soil sample before the introduction of the amendments revealed that total petroleum hydrocarbon (TPH) content in the soil sample was $25,350.2 \pm 0.21 \mathrm{mg} /$ $\mathrm{kg}$. This value obtained from the polluted soil is above the DPR intervention limit of $5000 \mathrm{mg} / \mathrm{kg}$, which means the polluted area would require remedial actions. The results of total heterotrophic and hydrocarbon utilizing bacterial counts includes: $8.7 \pm 0.03 \times 10^{5}$ $\mathrm{Cfu} / \mathrm{g}$ for THB, $4.1 \pm 0.05 \times 10^{5} \mathrm{Cfu} / \mathrm{g}$ for $\mathrm{HUB}, 9.0 \pm 0.04 \times 10^{4} \mathrm{Cfu} / \mathrm{g}$ for Fungi and $3.0 \pm 0.06 \times 10^{4} \mathrm{Cfu} / \mathrm{g}$ for HUF. The following bacterial and fungal genera were identified: Bacillus, Alcaligene, Vibrio Arthrobacter, Micrococcus, Serratia, Klebsiella, Pseudomonas and Aspergillus, Fumigatus, Penicillium, Mucor, Rhizopus. This shows that there were active indigenous microorganisms in the polluted soil that could bring about the biodegradation of TPH in the soil.

Microbial counts were carried out during the bioremediation, by monitoring in every 7days for a period of 28 days under laboratory conditions. Microbial activities were confirmed during monitoring by quantification and identification of pure isolates of total heterotrophic bacterial counts (THB), total fungal counts (TFC), hydrocarbon utilizing bacterial (HUB) and hydrocarbon utilizing fungal (HUF) counts ineach setup. The total heterotrophic bacterial counts ranged from $1.3 \pm 0.05 \times 10^{5}$ to $2.3 \pm 0.04 \times 10^{6} \mathrm{Cfu} / \mathrm{g}$ across the treatment options. The highest total heterotrophic bacterial counts $2.3 \pm 0.04 \times 10^{6} \mathrm{Cfu} / \mathrm{g}$ was observed in setup 4 on day 14 and the least count was observed in the control on day 28 which had $1.3 \pm 0.05 \times 10^{5} \mathrm{Cfu} / \mathrm{g}$. Total fungal counts ranged from $9.0 \pm$ $0.01 \times 10^{4}$ to $7.0 \pm 0.01 \times 10^{5} \mathrm{Cfu} / \mathrm{g}$, setup 2 had the highest population of $7.0 \pm 0.01 \times 10^{5} \mathrm{Cfu} / \mathrm{g}$ on day 7 and setup 4 had the least population of $9.0 \pm 0.01 \times 10^{4} \mathrm{Cfu} / \mathrm{g}$ on day 28 . Hydrocarbon utilizing bacterial (HUB) counts ranged from $1.0 \pm 0.04 \times 10^{5}$ to $1.32 \pm$ $0.04 \times 10^{6} \mathrm{Cfu} / \mathrm{g}$ across the experimental setups, the highest counts were from setup $3,1.3 \pm 0.04 \times 10^{6} \mathrm{Cfu} / \mathrm{g}$ on day 14 and the least from control, $1.0 \pm 0.04 \times 10^{5} \mathrm{Cfu} / \mathrm{g}$ on day 28 . Hydrocarbon utilizing fungi (HUF) counts ranged from $7.0 \pm 0.02 \times 10^{4}$ to $5.1 \pm 0.18 \times$
$10^{5} \mathrm{Cfu} / \mathrm{g}$ across the setups. The highest population was observed in setup 2 on day 14 and the least population was seen in control on day 0 .

The concentrations of hydrocarbons in the polluted soil in each treatment option reduced over time as seen in figures 1 . TPH (comprising of $\mathrm{C}_{8}-\mathrm{C}_{35}$ ) total on day 0 was $25,350.24 \pm 0.00 \mathrm{mg} / \mathrm{kg}$, this was reduced after 28 days to $23,813.44 \pm 1.32 \mathrm{mg} / \mathrm{kg}$ in control, $6,203.11 \pm 1.21 \mathrm{mg} / \mathrm{kg}$ for CS, 2,972.74 $\pm 0.13 \mathrm{mg} / \mathrm{kg}$ for FPE and $4,532.34 \pm 0.08 \mathrm{mg} / \mathrm{kg}$ for SMS. Figure 1 shows the percentage reduction of TPH. Also, figures 2 to 5 shows the level of hydrocarbon concentration reduction in each treatment option over the bioremediation period. Plates 1 to 12 show the chromatogram of the various experimental setups.

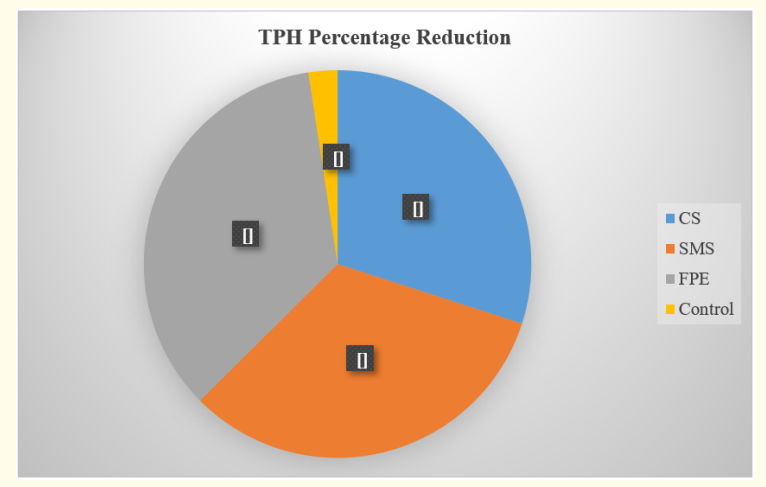

Figure 1: Percentage Reduction across the Treatment Options for TPH after Bioremediation.

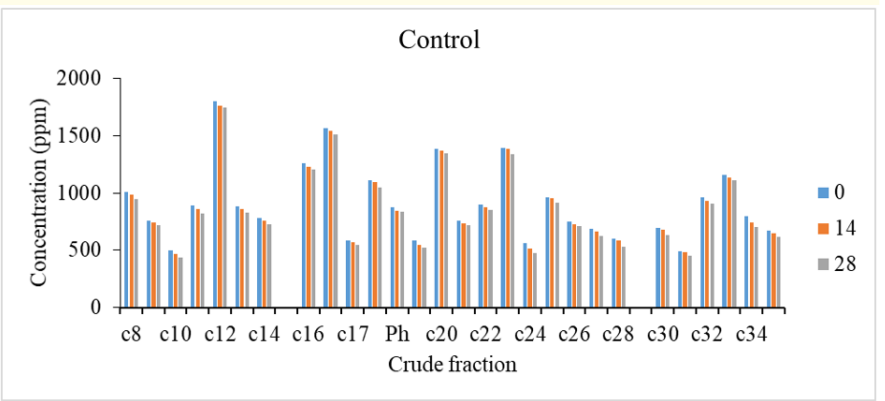

Figure 2: Reduction in the Concentration of Different Hydrocarbon Components in Control Treatment Option. 


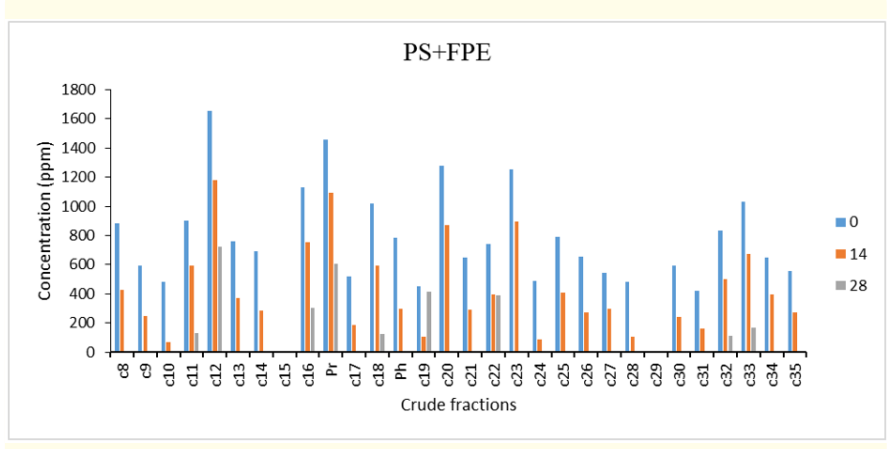

Figure 3: Reduction in the Concentration of Different Hydrocarbon Components in FPE Treatment Option.

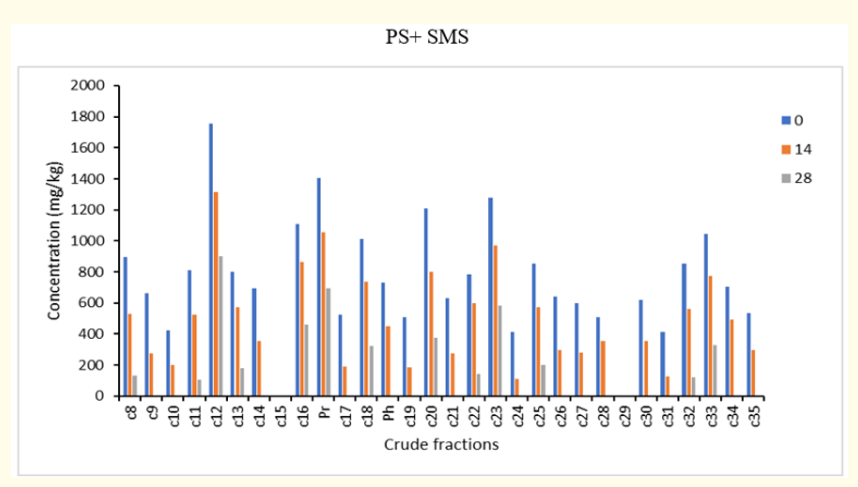

Figure 4: Reduction in the Concentration of Different Hydrocarbon Components in SMS Treatment Option.

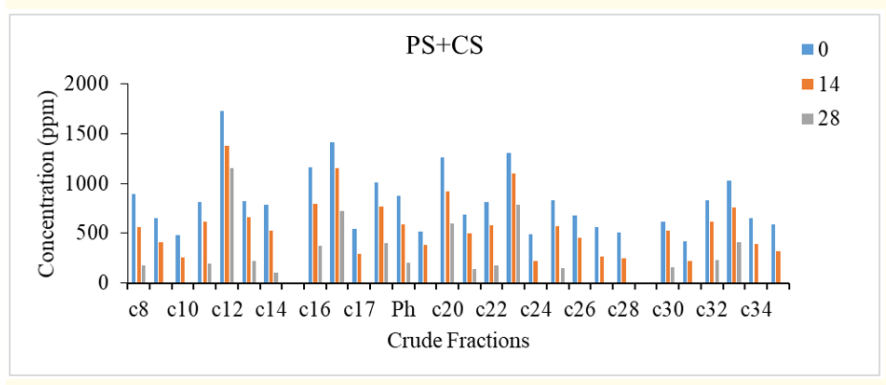

Figure 5: Reduction in the Concentration of Different Hydrocarbon Components in CS Treatment Option.

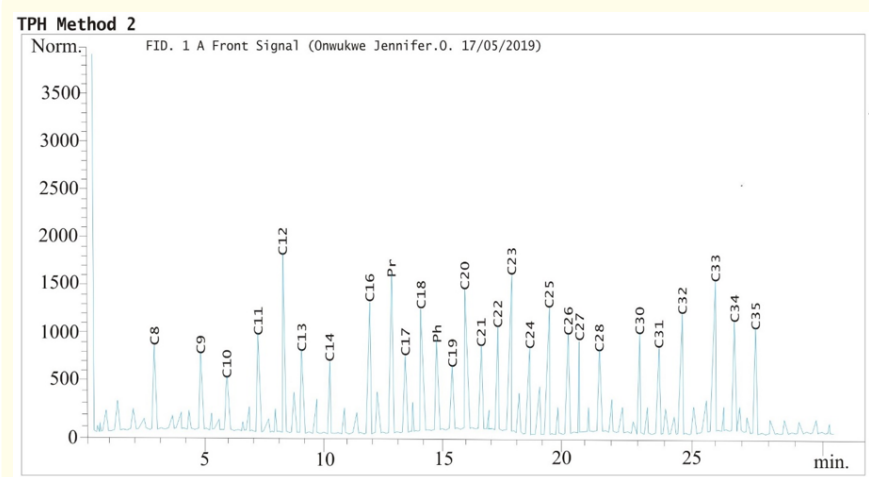

Plate 1: Day 0 TPH control chromatogram.

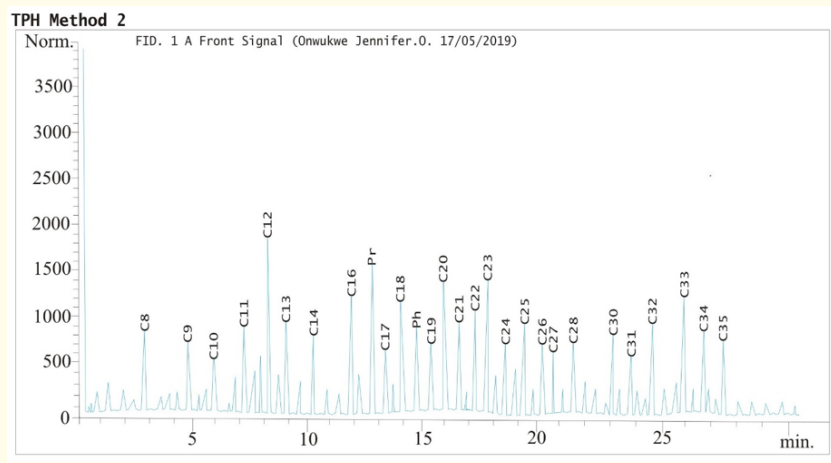

Plate 2: Day 0 TPH FPE chromatogram.

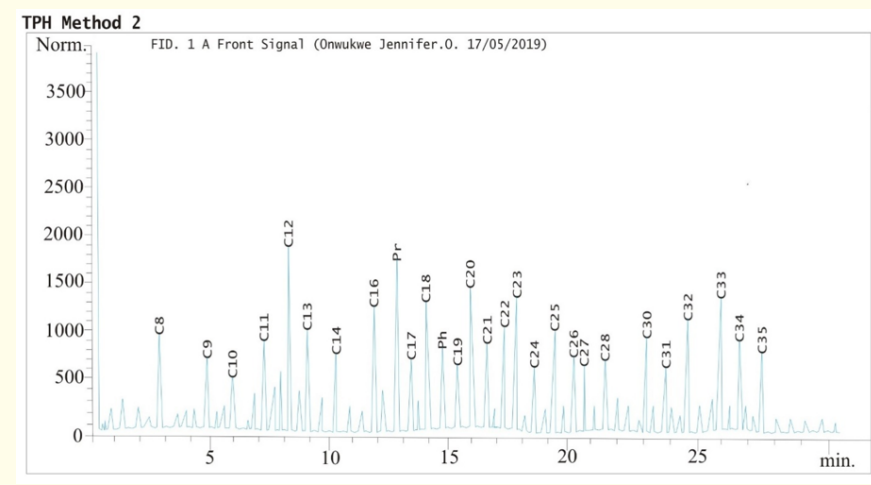

Plate 3: Day 0 TPH SMS chromatogram. 


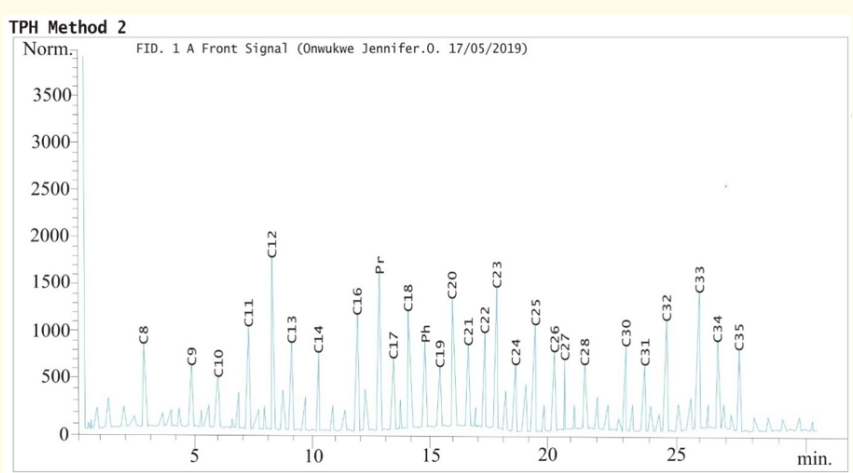

Plate 4: Day 0 TPH SMS chromatogram.

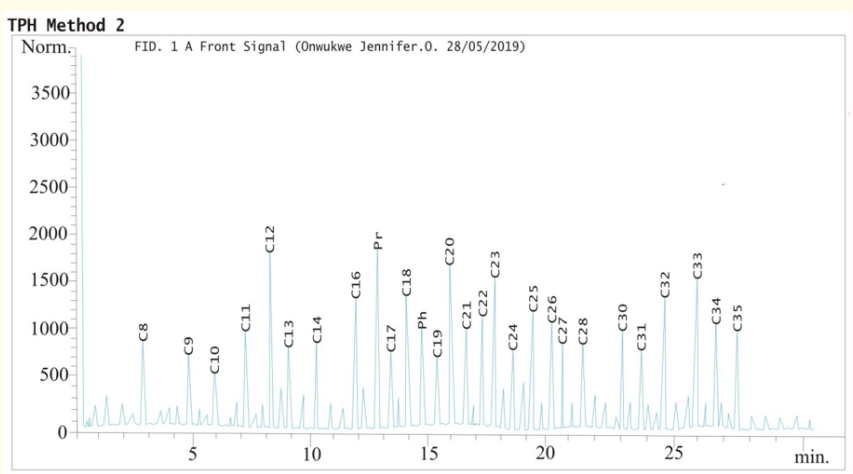

Plate 5: Day 14 TPH control chromatogram.

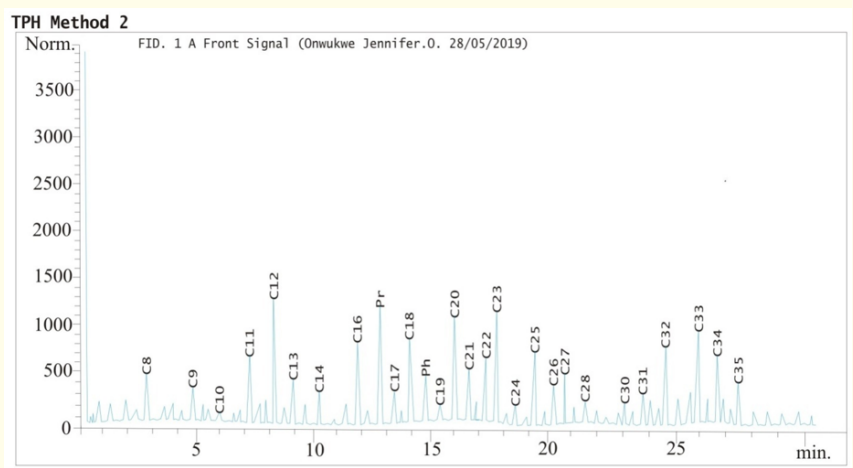

Plate 6: Day 14 TPH FPE chromatogram.

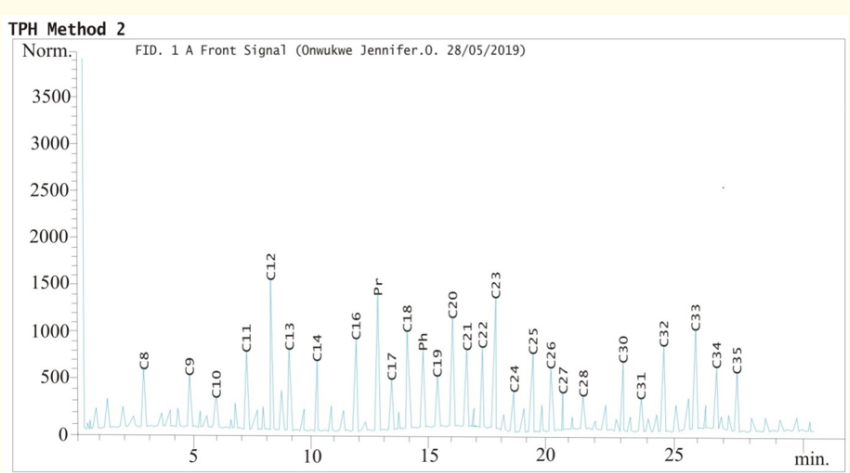

Plate 7: Day 14 TPH CS chromatogram.

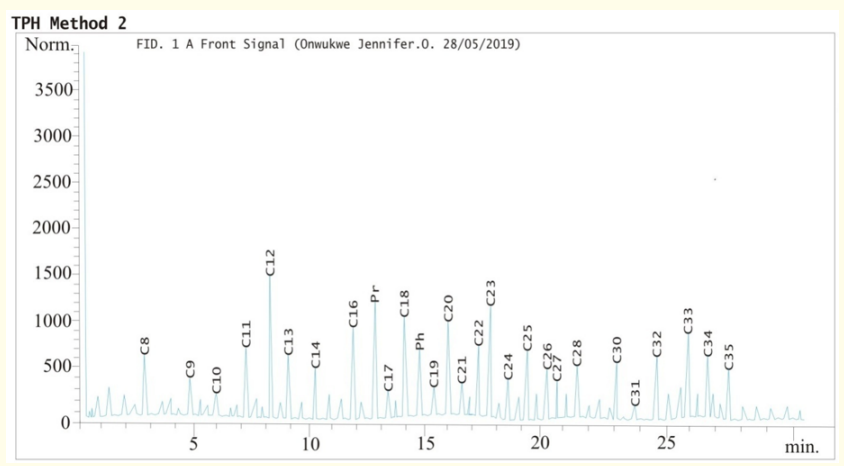

Plate 8: Day 14 TPH SMS chromatogram.

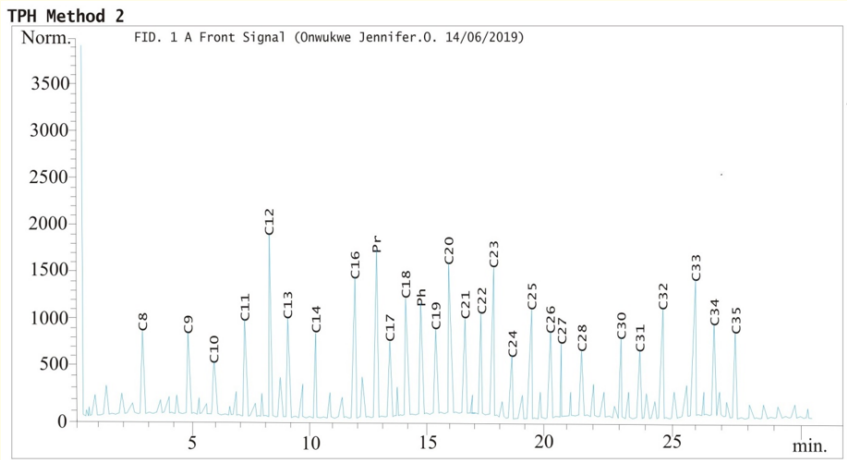

Plate 9: Day 28 TPH control chromatogram. 


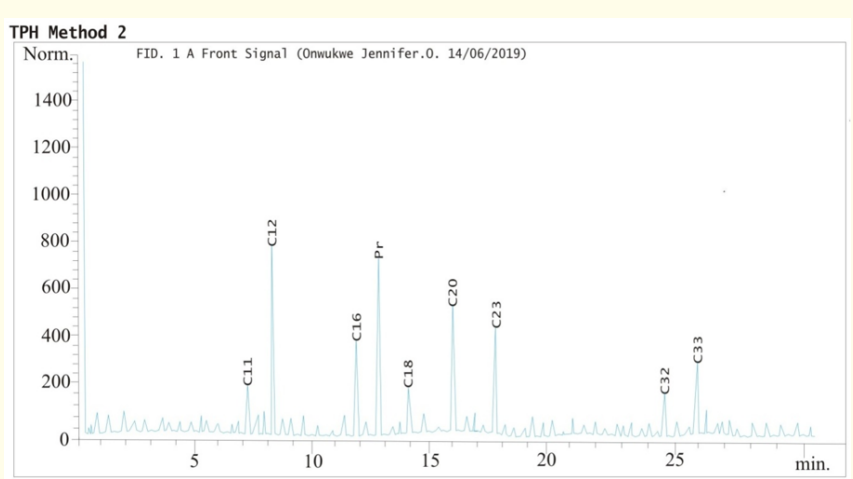

Plate 10: Day 28 TPH FPE chromatogram.

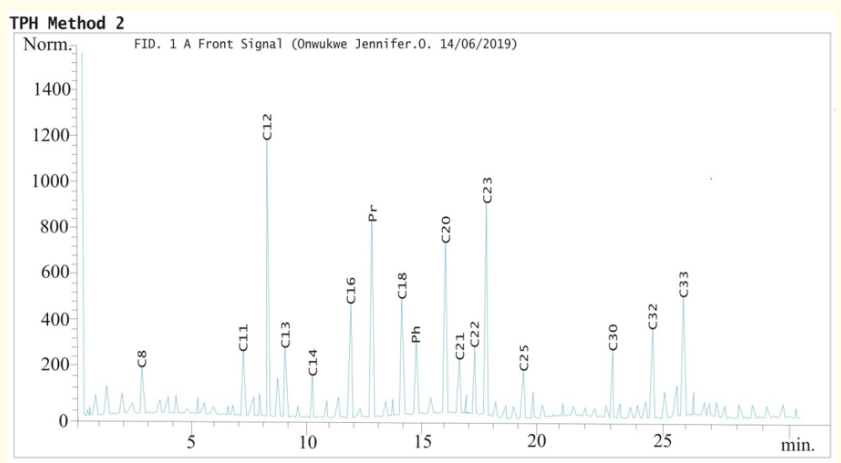

Plate 11: Day 28 TPH CS chromatogram.

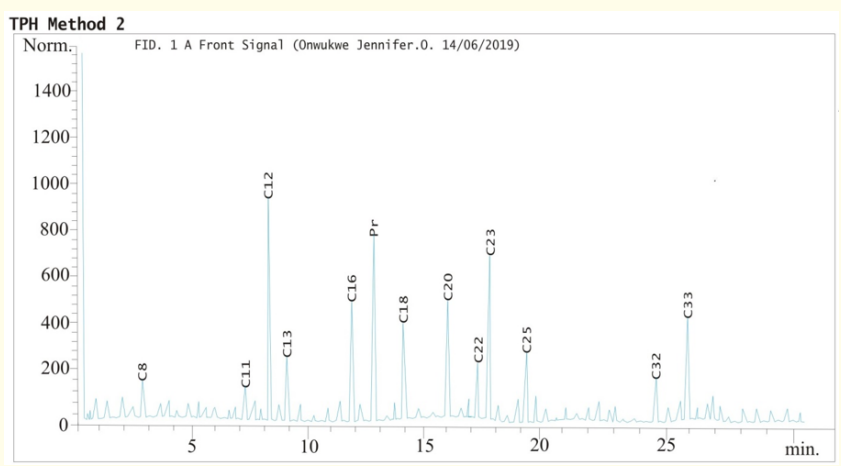

Plate 12: Day 28 TPH SMS chromatogram.

\section{Discussion}

This study was carried out to evaluate the effectiveness of organic amendments in the biodegradation of hydrocarbon polluted soil. The results of the baseline study indicate that TPH concentrations were higher than the DPR intervention limit of greater than $5,000 \mathrm{mg} / \mathrm{kg}$ [21] in the soil from the study area. Fishpond effluent, spent mushroom substrate and Compost soil were used as sources of amendment for the bioremediation of polluted soil in order to evaluate their individual abilities in degrading high concentrations of TPHs. Also, these organic wastes used in this study are abundant within the area and may constitute a form of nuisance in the environment as a result of improper disposal and management. Therefore, the need of channeling them into a more useful and effective environmental waste management.

The presence of light carbon chain petroleum hydrocarbons observed in the polluted soil sample may have been the reason for the moderate counts of total heterotrophic bacterial and fungal counts $\left(10^{5} \mathrm{Cfu} / \mathrm{g}\right)$. This showed that some of the THB and TFC were also able to utilize and degrade TPHs [22] and the HUB and HUF had adapted the ability to grow in the presence of these hydrocarbons and are able to utilize these substances as sources of carbon and energy. Moderate counts of THB, HUB, THF and HUF shows the presence of active microbial populations in the soil. This may be due to the presence of organic carbon and other environmental conditions that encourages the growth of the microorganisms. This also shows that even though the pollutant may be inhibitory to certain group of bacteria and fungi present in the soil, others have the ability to grow and utilize these substances as sources of carbon and energy. The presence of these pollutants resulted in selective enrichment of the microorganisms present, a reduction in the overall types of microorganisms present and increase in hydrocarbon utilizing microorganisms [15].

The addition of the different organic amendments led to increase in the growth of bacteria and fungi thus, in the degradation of TPHs, reducing the concentration from days 0 to 28. This corresponds with the study carried out by Abioye., et al. [23] where they observed biostimulation to be more effective in removing pollutants than bioaugumentation. 
The bacterial counts in fish pond effluent (FPE) had lower total heterotrophic bacteria and hydrocarbon utilizing bacterial counts than the other amendments but higher fungal counts yet had the highest TPH degradation. This may be due to the organic amendments added which served as a bulking agent, improved aeration, increased synergistic relationship between the bacterial and fungal population, moisture holding capacity was also increased which in turn increased the biodegradation rate [20]. The synergistic relationship between the bacterial and fungal community leading to increased degradation of the hydrocarbons is in accordance with studies carried out by Martens and Zadrail [24]; where they recorded double increase in the biodegradation of hydrocarbons as a result of synchronous activity of both bacteria and fungi. The microbial quality in FPE decreased with rapid depletion of hydrocarbons due to the decline of nutrients contained in the treatment setup and formation of byproducts as the microbial population increased. FPE had a half-life of 9.6 days with degradative potential of $88.27 \%$ for TPH indicating that it would take FPE the shortest number of days to degrade half the amount of crude oil hydrocarbons in this polluted site and also has the highest potential of breaking down the hydrocarbons via the increased rate of metabolic activities of the indigenous microbes present in the polluted soil. This suggests that it might not have been microbial processes alone that led to the increased loss of these hydrocarbons, it might also be attributed to both physical and chemical processes like temperature, increased rate of nitrate utilization, aeration and moisture [25]. Hence, this shows that fish pond waste/ effluent can serve efficiently as a bioremediating agent.

Spent mushroom substrate (SMS) which is composed of sawdust had increase in hydrocarbon utilizing bacterial counts more than the other setups. This is in line with another research by Udotong., et al. [26] where they observed a rapid increase at the early stage of their bioremediation process which was attributed to the bacterial response to high concentrations of petroleum hydrocarbons. This organic amendment had the second highest TPH degradation of $82.12 \%$ with a half-life of 12.2 days which is lower than compost soil. The compost soil (CS) treatment option had more THB counts with TPH removal of $75.53 \%$ and a half-life of 14.81 days. Control setup, was non-amended (NA) and had the least TPH reduction of $6.1 \%$, and a longer half-life of 315.7 days. This indicate that a decrease in TPH concentration occurred, even in the absence of any amendment showing that the indigenous microbial popu- lation present may have developed the capability to breakdown these hydrocarbons, though this may take many days to degrade half the quantity of hydrocarbons present naturally. Both bacterial and fungal counts in the 4 microcosm setups were statistically significant $(p<0.05)$ meaning that each treatment could also be effective for degradation of hydrocarbons. Although the control (natural attenuation) will take longest time to remove or reduce the hydrocarbons to an acceptable limit as the indigenous bacteria and fungi surviving the effects of the pollution adapts and utilize the hydrocarbons as their main source of carbon based on their metabolic pathways [25].

Most of the TPHs were totally eliminated and the others reduced to lower concentrations in all amended setups but most especially in the FPE treatment setup. The individual concentrations of the hydrocarbon components present in TPH decreased in the presence of these organic wastes. It was observed that the control had very little reduction as compared to the amended treatment options where some of the carbons were totally eliminated and the remaining ones drastically reduced at the end of the bioremediating period. Greatest reduction of the hydrocarbon components was observed in the FPE treatment option, followed by SMS, while CS treatment options had the least of the amended. Results of the GC-FID analysis showed alkanes greater than C8. The absence of alkanes less than C8 may be due to volatilization of the lighter fractions over time after the spill, while the heavier alkanes partitions into the soil [27].

\section{Conclusion}

Illegal crude oil refining activities together with other anthropogenic activities in the Niger Delta contribute to the series of hydrocarbon pollution in the environment leading to many ecological damages. This study revealed increased concentrations of total petroleum hydrocarbons far greater than the intervention limit stated by the Department of Petroleum Resources in the soil from study area. This research has shown the degradation of TPH using different organic wastes used as amendments in the bioremediation of hydrocarbon polluted soil. At the end of the 28days monitoring period, the results indicated that the organic amendments added had significant biostimulatory effects on the TPH degradation as compared to the unamended (control). However, fishpond waste had the highest potential of breaking down the TPH via the increased rate of metabolic activities of the bacterial and fungal

Citation: Douglas Salome Ibietela., et al. "Bioremediation of Total Petroleum Hydrocarbon Polluted Soil From an Abadoned Illegal Crude Oil Refining Site Using Organic Amendments". Acta Scientific Microbiology 5.1 (2022): 70-79. 
communities present in the polluted soil, plus the organic waste added to the soil. Hence, it is recommended that fish pond effluent may be used for bioremediation of total petroleum hydrocarbon polluted environment.

\section{Bibliography}

1. Vamelari T., et al. "Field crops for phytoremediation of metal contaminated land-a review". Environmental Chemistry Letters 8 (2010): 1-17.

2. Erdogan E and Karaca A. "Bioremediation of crude oil polluted soils”. Asian Journal of Biotechnology, 3 (2011): 206-213.

3. Eckenfelder W W and Norris R D. "Applicability of biological processes for treatment of soils". American Chemical Society 518 (1993): 138-158.

4. Adebusoye SA., et al. "Microbial degradation of petroleum hydrocarbons in a polluted stream". World Journal of Microbial Biotechnology 23 (2007): 1149-1159.

5. Philp J C and Atlas R M. "Bioremediation of contaminated soils and aquifers". In: Atlas RM, Philp JC (eds) Bioremediation: applied microbial solutions for real-world environmental cleanup. American Society for Microbiology (ASM) Press, Washington (2005): 139-236.

6. Ramirez M I., et al. "Contamination by oil crude extractionrefinement and their effects on human health". Environmental Pollution 231 (2017): 415-425.

7. Margesin R and Schinner F. "Biodegradation and bioremediation of hydrocarbons in extreme environments". Applied Microbiology and Biotechnology 56 (2001): 650-663.

8. Sayara T., et al. "Preliminary screening of co-substrate for bioremediation of pyrene- contaminated soil through compositing". Journal of Hazardous Materials 172 (2009): 1695 -1724.

9. Wang X., et al. "Effect of biostimulation on community level physiological profiles of microorganisms in field- scale biopiles composed of aged oil sludge". Bioresource Technology 111 (2012b): 308-315.

10. Santos E S., et al. "Effects of organic/inorganic amendments on trace elements dispersion by leachates from sulfidecontaining tailings of the S ao Domingos mine, Portugal. Time evaluation". Geoderma, 226.227 (2014): 188-203.
11. Mohammed D., et al. "An assessment of the biodegradation of petroleum hydrocarbons in contaminated soil using non-indigenous, commercial microbes". Water, Air and Soil Pollution 182 (2007): 349-356.

12. Shaopeng Y., et al. "Characterization of Oil-Degrading Bacteria from Oil-Contaminated Soil and Activity of their Enzymes". Biotechnology and Biotechnological Equipment 27.4 (2013): 3932-3938.

13. Chikere CB., et al. "Comparative Effectiveness of Activated Soil in Bioremediation of a Farmland Polluted Soil by Polyaromatic Hydrocarbon in the Niger Delta". Journal of Bioremediation and Biodegradation 9.6 (2018): 456-467.

14. Seo JC., et al. "Bacteria degradation of aromatic compounds". International Journal of Environmental Research and Public Health 6 (2009): 278-309.

15. Douglas S I., et al. "Effects of Three Organic Amendments on Polycyclic Aromatic Hydrocarbon Degradation from Oil Polluted Artisanal Refining Site". International Journal of Current Microbiology and Applied Sciences 9.12 (2020): 488-502.

16. Mills A L., et al. "Enumeration of petroleum-degrading marine and estuarine microorganisms by the most probable number". Canadian Journal of Microbiology 24.5 (1978): 552-557.

17. Okpokwasili G C and Okorie B B. "Biodeterioration potentials of microorganisms isolated from car engine lubricating oil”. Tribology International 21.4 (1988): 215-220.

18. Cheesebrough M. "District Laboratory Practice in Tropical Countries". Part 2, Cambridge University Press, London, UK (2000): 143-156.

19. Yang Z., et al. "Evaluation of Total petroleum hydrocarbon measurement methods for assessing oil contamination in soil”. Environmental Forensics 14.3 (2013): 193-203.

20. Ekwuabu C B., et al. "Effect of different nutrient amendments on eco-restoration of a crude oil polluted soil". Society of Petroleum Engineers (2016): 1-7.

21. Environmental Guidelines and Standards for the Petroleum Industry in Nigeria (EGASPIN). Department of Petroleum Resources (DPR). $3^{\text {rd }}$ Edition, Lagos (2018): 183-184. 
22. Alrumman S A., et al. "Effects of hydrocarbon contamination on soil microbial community and enzyme activity". Journal of King Saud University 27 (2015): 31-41.

23. Abioye P 0., et al. "Enhanced biodegradation of used engine oil in soil amended with organic wastes". Water Air Soil Pollution 209 (2010): 173-179.

24. Martens R and Zadrazil F. "Screening of white-rot fungi for their ability to mineralize polycyclic aromatic hydrocarbons in soil". Folia Microbiology 43 (1998): 97-103.

25. Eman K and Andrew S B. "Soil bioremediation approaches for petroleum hydrocarbon polluted environments". AIMS Microbiology 3.1 (2017): 25-49.

26. Udotong I R., et al. "Bioconversion of crude oil production sludge into soil conditioner using sawdust as organic amendment". Geosystem Engineering 14.2 (2011): 51-58.

27. Chikere C B., et al. "Bacterial community dynamics of nutrient enhanced oil-polluted sediment". Nigerian Journal of Microbiology 30.1 (2016): 3281-3294.

\section{Assets from publication with us}

- Prompt Acknowledgement after receiving the article

- Thorough Double blinded peer review

- Rapid Publication

- Issue of Publication Certificate

- High visibility of your Published work

Website: www.actascientific.com/

Submit Article: www.actascientific.com/submission.php

Email us: editor@actascientific.com

Contact us: +919182824667 